\title{
Isolation and Antifungal Activity of Plant Lectins against some Plant Pathogenic Fungi
}

\author{
Soad F. E. Mohsen ${ }^{1}$, Moustafa A. Abbassy ${ }^{2}$, Entsar I. Rabea ${ }^{2}$, Hamdy K Abou-Taleb ${ }^{1}$
}

\begin{abstract}
Two lectins from seeds of white kidney bean (Phaseoulus vulgaries) and Soybean (Glycine max) were isolated and purified from saline crude extracts of seeds using ammonium sulfate precipitation. The two pure lectins were tested in vitro against two plant pathogenic fungi, Fusarium oxysporum and Rhizoctonia solani. Mycelial growth inhibition technique was performed in accordance with standard protocols to evaluate antifungal activity. Mycelial of both tested fungi were inhibited by the lectins extracts. Results revealed that, the lectin from Phaseoulus vulgaries (LP lectin) had a higher antifungal activity against $F$. oxysporum $\left(\mathrm{EC}_{50}=\mathbf{5 0 5 8}, 4872\right.$ and 3617 $\mathrm{mg} / \mathrm{L}$, after 48, 72 and $120 \mathrm{~h}$, respectively). Inaddition, the antifungal activity of LP lectin against $R$. solani was higher than lectin from Glycine max (LG lectin) with $\mathrm{EC}_{50}$ values 6786, 6646 and $5465 \mathrm{mg} / \mathrm{L}$ after 48,72 and $120 \mathrm{~h}$, respectively,
\end{abstract}

Keywords: Lectin, Phaseolus vulgaris, Glycine max, Antifungal activity, Fusarium oxysporum, Rhizoctonia solani.

\section{INTRODUCTION}

Agricultural losses are a challenging economic and food security problem. Global food security is threatened by population growth and the emergence and spread of crop pests, which are significantly increasing with climate change (Bebber et al., 2013).

The search for new compounds with antifungal activity is accelerating due to increase fungal resistance to commonly prescribed fungicides. Among the molecules being investigated, plant lectins can be highlighted. Lectins are carbohydrate-binding proteins, which are highly variable in their amino acid sequences, and with different functions, structures, tissue localizations and carbohydrate-binding specificities. They bind reversibly to specific carbohydrates present on the opposing cells, which are responsible for their ability to agglutinate red blood cells, lymphocytes, fibroblasts. Lectins widely distributed in microorganisms, viruses, animals and higher plants, Plant lectins were classified into seven families according to their evolutionary and structural characteristics, one of which is the legume lectin family (Van Damme et al., 1998). Lectins have been found in many plant groups, including mono- and dicotyledons,

\footnotetext{
${ }^{1}$ Plant Protection Research Institute, Agricultural Research Center,

Sabahia, Alexandria, Egypt

${ }^{2-}$ Department of Plant Protection, Faculty of Agriculture, Damanhour

University, Damanhour, Egypt

Received March 03, 2018, Accepted March 31, 2018
}

but most frequently, they have been detected in Leguminoseae and Euphorbiaceae. Lectins are distributed in various plant tissues. Many plants contain lectins, including different food crops such as wheat, rice, potato, tomato, soybean and bean. Lectin extraction is usually achieved using different methods of diffusion in aqueous solution and ammonium sulfate precipitation. Plant lectins play an important role in defense mechanisms against the attack of microorganisms (Ripoll et al., 2003; S? et al., 2009). These lectins have been demonstrated to inhibit the growth of several phytopathogenic fungi (Ang et al., 2014).

The targets of some plant lectins are fungi that present chitin in their cell walls, resulting in inhibitory action on the growth and development of these microrganisms (Ciopraga et al., 1999). A number of diverse physiological roles have been proposed for plant lectins, including, antifungal (Barrientos and Gronenborn, 2005), antiviral (Van Asbeck et al., 2008) and anti-insect activities (Singh et al., 2006). The Phthirusa pyrifolia lectin was an antifungal agent on Fusarium lateritium and Rhizoctonia solani but did not affect the growth of Aspergillus niger, A. fumigatus, Rhizopus arrhizus, Paecilomyces variotti and $F$. moniliforme. The effect of lectin on growth of A. niger, $F$. oxysporum, F. moniliforme and Trichoderma viride was investigated and the lectin was active only on Fusarium species. A stable, ion dependent and chitinbinding lectin isolated from Opuntia ficus-indica cladodes was able to affect the growth of $F$. oxysporum and F. solani (Santana et al., 2009). The lectin isolated from Ophiopogonjaponicus rhizomes was an antifungal agent against the phytopathogens Gibberella saubinetii and $R$. solani but not on Penicillium italicum (Tian et al., 2007). The lectin of Pisum sativum seeds inhibited the growth of $F$. oxysporum and Trichoderma viride (Sitohy et al., 2007).

The present study reports the purification, characterization and evaluation of antifungal potential of two plant lectins isolated from two plants, white kidney bean (Phaseoulus vulgaries) and Soybean (Glycine max) against plant pathogenic fungi, root rot disease $F$. oxysporum and $R$. solani. 


\section{MATERIALS AND METHODS}

\section{Chemicals and reagents}

Bovine serum albumin (BSA) and ammonium sulphate were purchased from Sigma-Aldrich Co. (USA). Potato Dextrose Agar (PDA) medium was purchased from Oxoid Ltd. (Basingstoke, Hampshire, UK).

\section{Microorganisms}

The two fungal species used in the bioassay for lectin antifungal activity were Fusarium oxysporum (Family: Nectriaceae; Class: Sordariomycetes) and Rhizoctonia solani (Family: Ceratobasidiaceae; Class: Agaricomycetes) which provided by Microbiology Laboratory, Department of Plant Pathology, Faculty of Agriculture, Alexandria University, Alexandria, Egypt, and kept during the experiments on PDA medium at 27 $\pm 2{ }^{\circ} \mathrm{C}$.

\section{Extraction of Phaseoulus vulgaries seeds lectin}

The P. vulgaries (white kidney bean) seeds were obtained from Legume Research Institute, Agricultural Research Centre, Ministry of Agricultural, Giza, Egypt, for isolation and purification of lectin. White kidney beans were ground to a powder in an electric mill and filtered through 80 mesh grid. The powder was mixed with $0.15 \mathrm{M} \mathrm{NaCl}(1: 8, w / v)$ for $48 \mathrm{~h}$ at 4 ? $\mathrm{C}$, and filtered through 80 mesh grid. Subsequently, the filtrate was centrifuged at $9168 \times \mathrm{g}$ for $30 \mathrm{~min}$ and the supernatant was used for step of purification (Hou et al., 2010).

\section{Purification of $\boldsymbol{P}$. vulgaries seeds lectin}

The supernatant was fractionally precipitated with ammonium sulfate $60 \%$ saturation, respectively. The pellets were combined, dissolved in a minimal volume of water, and dialyzed against distilled water at 4 ?C.

\section{Extraction of Glycine max seeds lectin}

The Soybean seeds were obtained from Legume Research Institute, Agricultural Research Centre, Ministry of Agricultural, Giza, Egypt, for isolation and purification of lectins. Soybean seeds were taken and grinded in a mixer for removal of seed coats and $50 \mathrm{~g}$ of uncoated seed were taken for the study. The uncoated seeds were soaked in phosphate buffer saline (PBS) for overnight. Then the seeds are grinded with minimum volume of PBS and the pastes were collected in $50 \mathrm{ml}$ centrifuge tubes and were centrifuged at $4[\mathrm{C}$ and 7500 rpm for 20 min and the supernatant was used for step of purification as salting out process (Bhol, 2012).

\section{Purification of $G$. max seeds lectin (LG)}

The supernatant was fractionally precipitated with ammonium sulfate at $60 \%$ saturation. The pellets were dissolved in a minimal volume of water and dialyzed against distilled water at $4 \square \mathrm{C}$.

\section{Determination of Protein Concentration}

Lowry et al. (1951) method was used for protein quantification, using bovine serum albumin (BSA) as the standard. The relative protein concentration of the eluted fractions was determined by measuring the absorbance at $690 \mathrm{~nm}$.

\section{Hemagglutinating Activity Assay}

Hemagglutinating activity is the most commonly used assay for the detection of lectin in a sample due to the simplicity of implementation and ease visualization of agglutination. It defined as the reciprocal of the highest dilution of sample promoting full agglutination of erythrocytes (RBC). The hemagglutinating activity occurs when the lectins binds to carbohydrate from erythrocyte surface promoting a network among them. Hemagglutination on microtiter plate was performed with the LP and LS lectins (blood groups O). The strongest hemagglutination was visible using $2 \% \mathrm{RBC}$. The protein is able to agglutinate $\mathrm{RBC}-\mathrm{O}$ at a concentration of about $25 \mathrm{mg} / \mathrm{ml}$. Readings were recorded after about $30 \mathrm{~min}$ at room temperature, when the blank had fully sedimented. Specific activity was expressed as the number of hemagglutination units per mg protein.

\section{Antifungal activity of purified lectin}

The antifungal activity was tested using mycelia radial growth technique (El-Ghaouth et al., 1992). The compounds were dissolved in water and serial concentrations ranged from 50 to $3000 \mathrm{mg} / \mathrm{L}$ were tested. The aliquots of the stock solutions were added to the PDA medium and then transferred to. After solidification, Petri dishes were inoculated with a $5 \mathrm{~mm}$ in diameter mycelium fungi and incubated in the dark at $27 \pm 2 \square$ C. Fungal growth was measured when the control had grown to the edge of the plate. The inhibition of fungal growth was calculated as the percentage of inhibition of radial growth compared to the control after different time intervals $(48,72$ and 120 h). The effective concentration that inhibits $50 \%$ of mycelial growth $\left(\mathrm{EC}_{50}\right)$ for each compound was estimated by probit analysis (Finney 1971) using SPSS 21.0 software.

\section{Statistical analysis}

Statistical analysis was performed using SPSS 21.0 software (Statistical Package for Social Sciences, USA). All experiments were repeated 3 times.. The log doseresponse curves allowed determination of the $\mathrm{EC}_{50}$ values for the fungal bioassay according to the probit analysis (Finney 1971). The 95\% confidence limits of $\mathrm{EC}_{50}$ values were determined by the least-square regression analysis of the relative growth rate $(\%$ 
control) against the logarithm of the compound concentration.

\section{RESULTS AND DISCUSSION}

Extraction and Purification of lectin from $P$. vulgaries seeds

The lectin contents in $250 \mathrm{~g}$ of $P$. vulgaries seeds were ranged from $300-500 \mathrm{mg}$. The total protein concentrations in the pure lectin were in the range 118 $120 \mathrm{mg} / \mathrm{mL}$. Lectins are found in abundance in legume seeds. Phaseolus vulgaris is an herbaceous annual plant grown worldwide for its edible beans, popular in both dry and green bean forms. Lectins or hemagglutinins have been purified from different varieties of $P$. vulgaris. The lectin contents are low in some varieties and high in other varieties. The lectin contents in some parts of plants are higher, e.g., 390 and $75 \mathrm{mg}$ of the purified lectin was recovered from 100 g Remusatia vivipara tubers (Bhat et al., 2010) and Astragalus mongholicus roots (Yan et al., 2005), respectively. The lectin content in non-legume plants is low, e.g., $3.3 \mathrm{mg}$ lectin from $100 \mathrm{~g}$ Hibiscus mutabilis seeds (Lam and $\mathrm{Ng}, 2009)$. In this study, lectin extracted from seeds of $P$. vulgaries with $0.15 \mathrm{M} \mathrm{NaCl}$ for $48 \mathrm{hrs}$ as shown in Figure 1. Isolation of lectins achieved by an ammonium sulfate $60 \%$ to precipitate lectins as schematized in Figure 1. Lectins can be extracted from plant tissue with water, $0.15 \mathrm{M} \mathrm{NaCl}$ or buffer solutions when it is necessary to control $\mathrm{pH}$ for the maintenance of hemagglutinating activity. The temperature and extraction time depends on stability and solubility of the lectin and may vary from 4 to 27 ? $\mathrm{C}$, from minutes to hours. Isolation of lectins can be achieved by a combination of different purification techniques. Acids (e.g., acetic acid used by Naeem et al., (2007), organic solvent (e.g., acetone used by Medeiros et al., (2010) or salt (e.g., ammonium sulfate) can be used to precipitate lectins.

Extraction and Purification of lectin from G. $\max$ seeds

The present study represents the investigation on the purification of a lectin from G. $\max$ seeds. $60 \%$ saturation ammonium sulphate precipitation and dialysis as shown in Figure 2. The lectin contents in $250 \mathrm{~g}$ of $G$. max seeds were ranged from $500-700 \mathrm{mg}$. The total protein concentrations in the pure lectin were in the range $160-163 \mathrm{mg} / \mathrm{mL}$. The soybean $(G$. max $)$ is a legume species native to East Asia, which is highly cultivated for its edible seed. Soybean is one of the most important bean among all in the world, which provides vegetable protein for millions of human and ingredients for thousands of chemical products. Soybean lectin isolated from G. $\max$ is a carbohydrate binding protein highly specific to terminal non-reducing $N$-acetyl-Dgalactosamine but less to D-galactose.

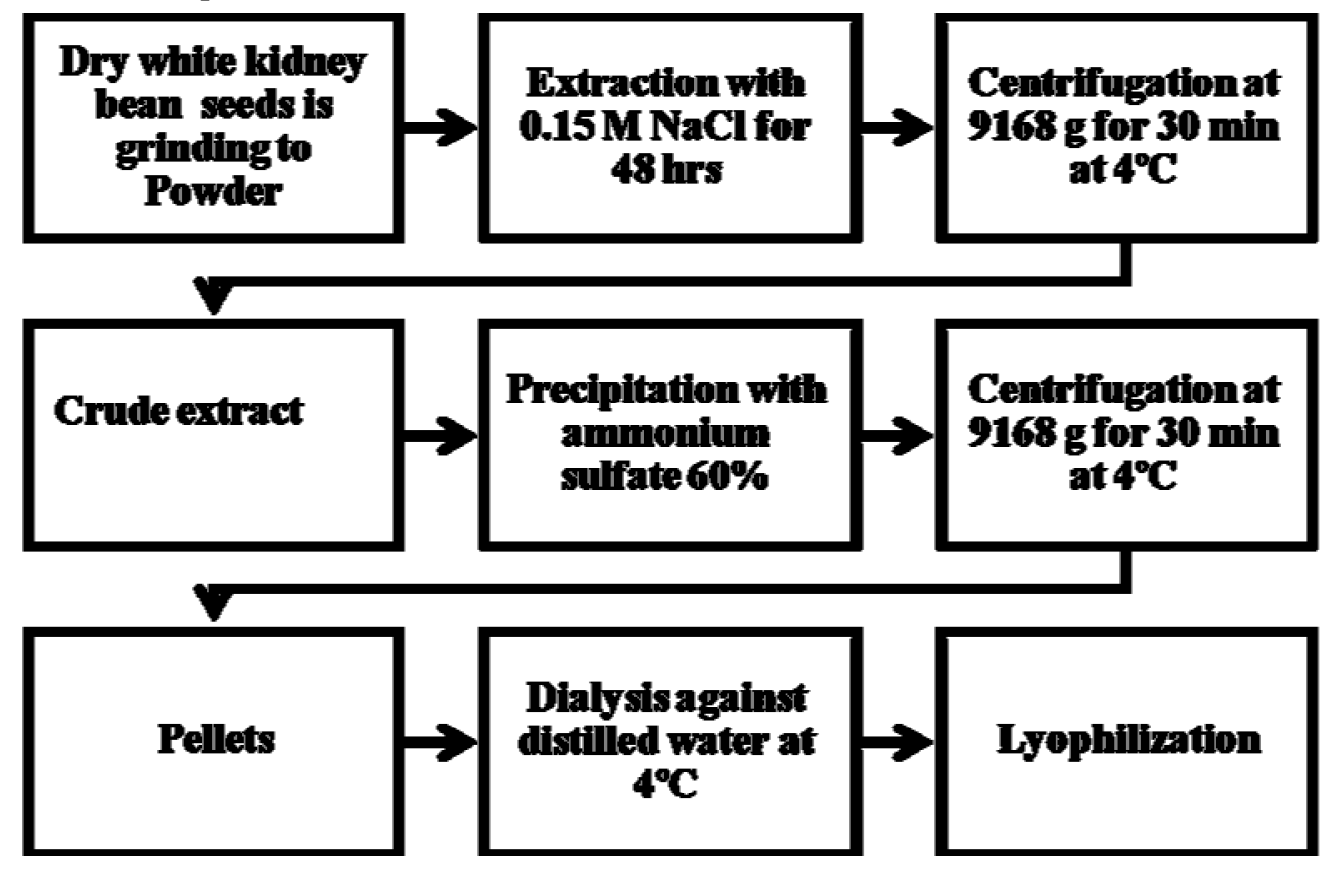

Figure 1. Scheme for isolation and purification of lectin from white kidney bean 


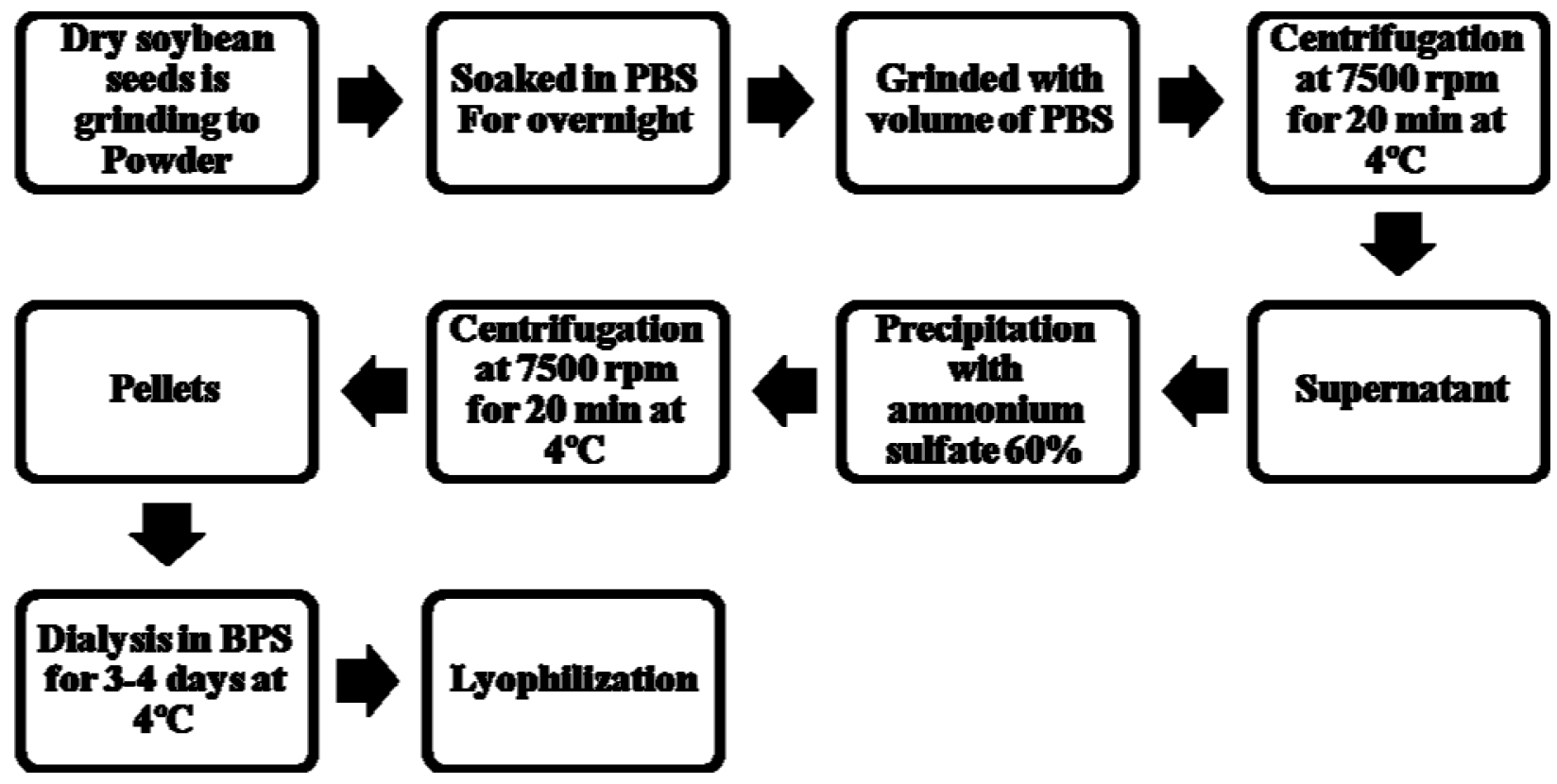

Figure 2. Scheme for isolation and purification of lectin from soybean

The in vitro antifungal activity of pure lectins

The in vitro antifungal activity of pure lectins from $G$. $\max (\mathrm{LG})$ and $P$. vulgaries (LP) against $F$. oxysporum, and $R$. solani fungi was estimated by determination the concentration causing $50 \%$ mycelial growth inhibition $\left(\mathrm{EC}_{50}\right)$ as shown in Tables 1 and 2 . The mycelial growth inhibition was recorded after different time intervals, 48, 72 and 120 hrs. All lectins had higher inhibition against the tested fungi according to the type of lectin and microorganism. The antifungal activity of pure lectins against the soil borne fungus $F$. oxysporum (Table 1) indicated that the LP was the most potent among the tested compounds with $\mathrm{EC}_{50}$ of 5058, 4872 and $3617 \mathrm{mg} / \mathrm{L}$, after 48, 72 and $120 \mathrm{hrs,}$ respectively. In contrast, the LG was the lowest active compounds with $\mathrm{EC}_{50}$ of 13982, 9449 and $5635 \mathrm{mg} / \mathrm{L}$ after 48, 72 and 120 hrs against the same fungus, respectively. It can be concluded that the mycelial growth inhibition is time dependent.

The antifungal activity against the soil borne fungus $R$. solani (Table 2$)$ showed that the LP $\left(\mathrm{EC}_{50}\right.$ of 6786 , 6646 and $5465 \mathrm{mg} / \mathrm{L}$ after 48, 72 and $120 \mathrm{hrs}$, respectively) was more active than the LG ( $\mathrm{EC}_{50}$ of 13982, 9449 and $5635 \mathrm{mg} / \mathrm{L}$ after 48, 72 and $120 \mathrm{hrs,}$ respectively). In general, these results revealed that myselial growth inhibition was time dependent and the soil-borne pathogenic fungus $F$. oxysporum was more susceptible to the tested lectins than the soil borne fungus $R$. solani.
The expression of Gastrodia elata lectins in the vascular cells of roots and stems was strongly induced by the fungus Trichoderma viride, indicating that lectin is an important defense protein in plants (S? et al., 2009). Following insertion of the precursor gene of stinging nettle isolectin I into tobacco, the germination of spores of Botrytis cinerea, Colletotrichum lindemuthianum, and $T$. viride was significantly reduced (Ferreira et al., 2007). Thus, lectins may be introduced into plants to protect them from fungal attack. Plant lectin may have indirect effects produced by the binding of lectins to carbohydrates on the fungal cell wall surface.

Chitinase-free chitin-binding stinging nettle (Urtica dioicalectin) impeded fungal growth. Cell wall synthesis was interrupted because of attenuated chitin synthesis and/or deposition (Munro et al., 2003). The effects of nettle lectin on fungal cell wall and hyphal morphology suggest that the nettle lectin regulates endomycorrhizal colonization of the rhizomes. Severa1 other plant lectins inhibit fungal growth. The first group includes small chitin-binding merolectins with one chitin-binding domain, e.g., hevein from rubber tree latex and chitin-binding polypeptide from Amaranthus caudatus seeds (Broekaert et al., 1992). A part from seeds, lectins were also found in both reproductive and vegetative tissues, such as fruits, leaves, flowers, roots etc. Lectins from various part of the plant are different in its efficiency against particular pathogen. The 
inhibition of fungi growth can occur through lectin binding to hyphas resulting in poor absorption of nutrients as well as by interference on spore germination process (Zvereva and Vysotskaya, 2005). Lectins from Alliaceae (Roy et al., 2002) and Zingeberaceae (Chen et al., 2005) have been reported for their insecticidal and anti-fungal properties that can be used for various applications. The activity of Archidendron jiringa lectin against the in vitro growth of Exserohilum turcicum, $F$. oxysporum and Colletotrichum cassiicola, showing that $5.7 \mu \mathrm{g} / \mathrm{mL}$ of purified protein resulted in complete inhibition (Charungchitrak et al., 2011). The polysaccharide chitin is constituent of fungi cell wall and chitin-binding lectins showed antifungal activity; impairment of

Table 1. The in vitro antifungal activity of pure lectins against $F$. oxisporum by using mycelial radial growth technique

\begin{tabular}{|c|c|c|c|c|c|c|}
\hline \multirow[b]{2}{*}{ Pure lectins } & \multirow{2}{*}{$\begin{array}{c}\mathrm{EC}_{50}{ }^{\mathrm{a}} \\
(\mathrm{mg} / \mathrm{L})\end{array}$} & \multicolumn{2}{|c|}{$95 \%$ confidence limits } & \multirow{2}{*}{$\begin{array}{c}\text { Slope }^{b} \\
\pm \text { SE }\end{array}$} & \multirow{2}{*}{$\begin{array}{c}\text { Intercept }^{\mathrm{c}} \\
\pm \mathrm{SE}\end{array}$} & \multirow{2}{*}{$\left(\chi^{2}\right)^{\mathrm{d}}$} \\
\hline & & Lower & Upper & & & \\
\hline \multicolumn{7}{|c|}{$48 \mathrm{hrs}$} \\
\hline LG & 13982 & 9272 & 31106 & $1.1 \pm 0.2$ & $-4.56 \pm 0.73$ & 2.59 \\
\hline $\mathbf{L P}$ & 5058 & 3891 & 7330 & $1.0 \pm 0.18$ & $-3.72 \pm 0.64$ & 1.77 \\
\hline \multicolumn{7}{|c|}{$72 \mathrm{hr}$} \\
\hline LG & 9449 & 6769 & 17221 & $1.07 \pm 0.19$ & $-4.23 \pm 0.68$ & 1.01 \\
\hline $\mathbf{L P}$ & 4872 & 3554 & 7832 & $0.82 \pm 0.18$ & $-3.02 \pm 0.62$ & 1.90 \\
\hline \multicolumn{7}{|c|}{$120 \mathrm{hr}$} \\
\hline LG & 5635 & 4293 & 8516 & $1.0 \pm 0.18$ & $-3.73 \pm 0.64$ & 0.05 \\
\hline $\mathbf{L P}$ & 3617 & 2653 & 5088 & $0.87 \pm 0.18$ & $-3.08 \pm 0.62$ & 0.86 \\
\hline
\end{tabular}

${ }^{\mathrm{a}}$ The concentration causing $50 \%$ mycelial growth inhibition.

${ }^{\mathrm{b}}$ Slope of the concentration-inhibition regression line \pm standard error.

${ }^{\mathrm{c}}$ Intercept of the regression line \pm standard error.

${ }^{\mathrm{d}}$ Chi square value.

LG, lectin from G. max; LP, lectin from $P$. vulgaries

Table 2. The in vitro antifungal activity of pure lectins against $R$. solani by using mycelia radial growth technique

\begin{tabular}{|c|c|c|c|c|c|c|}
\hline \multirow[b]{2}{*}{ Pure lectins } & \multirow{2}{*}{$\begin{array}{c}\mathrm{EC}_{50}{ }^{\mathrm{a}} \\
(\mathrm{mg} / \mathrm{L})\end{array}$} & \multicolumn{2}{|c|}{$95 \%$ confidence limits } & \multirow{2}{*}{$\begin{array}{c}\text { Slope }^{b} \\
\pm \text { SE }\end{array}$} & \multirow{2}{*}{$\begin{array}{l}\text { Intercept }^{\mathrm{c}} \\
\quad \pm \mathrm{SE}\end{array}$} & \multirow{2}{*}{$\left(\chi^{2}\right)^{d}$} \\
\hline & & Lower & Upper & & & \\
\hline \multicolumn{7}{|c|}{48 hrs } \\
\hline LG & 15563 & 10765 & 30475 & $1.45 \pm 0.24$ & $-6.06 \pm 0.87$ & 1.36 \\
\hline $\mathbf{L P}$ & 6786 & 5543 & 9022 & $1.54 \pm 0.20$ & $-5.88 \pm 0.73$ & 2.16 \\
\hline \multicolumn{7}{|c|}{72 hrs } \\
\hline LG & 11611 & 8412 & 20311 & $1.32 \pm 0.21$ & $-5.35 \pm 0.76$ & 0.81 \\
\hline $\mathbf{L P}$ & 6646 & 5455 & 8738 & $1.56 \pm 0.20$ & $-5.97 \pm 0.73$ & 1.12 \\
\hline \multicolumn{7}{|c|}{120 hrs } \\
\hline LG & 7781 & 5789 & 12829 & $1.08 \pm 0.19$ & $-4.19 \pm 0.67$ & 0.21 \\
\hline $\mathbf{L P}$ & 5465 & 4386 & 7381 & $1.25 \pm 0.19$ & $-4.66 \pm 0.67$ & 0.78 \\
\hline
\end{tabular}

${ }^{\mathrm{a}}$ The concentration causing $50 \%$ mycelial growth inhibition.

${ }^{\mathrm{b}} \mathrm{S}$ lope of the concentration-inhibition regression line \pm standard error.

${ }^{\mathrm{c}}$ Intercept of the regression line \pm standard error.

${ }^{\mathrm{d}}$ Chi square value.

LG, lectin from G. max; LP, lectin from P. vulgaries 


\section{REFERENCES}

Ang, A.S.W., R.C.F. Cheung., X. Dan., Y.S. Chan., W. Pan and T.B. Ng. 2014. Purification and characterization of a glucosamine-binding antifungal lectin from Phaseolus vulgaris cv. Chinese pinto beans with antiproliferative activity towards nasopharyngeal carcinoma cells. Appl. Biochem. Biotechnol. 172:672-686.

Barrientos L. G. and A. M. Gronenborn. 2005. The highly specific carbohydrate-binding protein cyanovirin-N: structure, anti-HIV/Ebola activity and possibilities for therapy. Mini-Reviews in Medicinal Chemistry, 5, 1:2131.

Bebber, D.P., M.A.T. Ramotowski and S.J. Gurr. 2013. Crop pests and pathogens move polewards in a warming world. Nat. Clim. Chang. 3: 985-988.

Bhat, G. G., K. N Shetty., N. N. Nagre., V. V. Neekhra., S. Lingaraju., R. S. Bhat., S. R. Inamdar., K. Suguna and B. M. Swamy. 2010. Purification, characterization and molecular cloning of a monocot mannose-binding lectin from Remusatia vivipara with nematicidal activity. Glycoconj J 27:309-320.

Bhol, C. S. 2012. Isolation and characterization of soybean (Glycine max) lectin- E-thesis. nitrkl.ac.in.

Boyd, L. A., Ridout, C. D. M. O'Sullivan., J. E. Leach and H. Leung. 2013. Plant-pathogen interactions: Disease resistance in modern agriculture. Trends Genet. 29:233240.

Broekaert, W. F., W. Mariën., F. R. Terras., M. F. De Bolle., P. Proost., J. VanDamme, L. Dillen., M. Claeys., S. B. Rees and J. Vanderleyden. 1992. Antimicrobial peptides from Amaranthus caudatus seeds with sequence homology to the cysteine/glycine-rich domain of chitinbinding proteins. Biochemistry 31:4308-4314

Charungchitrak, S., A. Petsom., P. Sangvanich and A. Karnchanatat. 2011. Antifungal and antibacterial activities of lectin from the seeds of Archidendron jiringa Nielsen. Food Chem; 126:1025-32.

Chen, Z., G. Kai., X. Liu., J. Lin., X. Sun and K. Tang. 2005. cDNA cloning and characterization of a mannose-binding lectin from Zingiber officinale Roscoe (ginger) rhizomes. Journal of biosciences, 30. 2:213-220.

Ciopraga, J., O. Gozia,. R. Tudor., L. Brezuica and R. J. Doyle. 1999. Fusarium sp growth inhibition by wheat germ agglutinin. Biochim. Biophys. Acta, 1428:424-432.

El-Ghaouth, A., J. Arul., J. Grenier and A. Asselin. 1992. Antifungal activity of chitosan on two postharvest pathogens of strawberry fruits. Phytopathology 82:398-402.

Ferreira, R. B., S. Monteiro., R. Freitas, C. N. Santos., Z. Chen., L. M. Batista., J. Duarte and A. R. Teixeira. 2007. The role of plant defense proteins in fungal pathogenesis. Molecular Plant Pathology, 8 (5):677-700.

Finney, D. J. (1971). Probit analysis, third ed. Cambridge University Press, London pp.318.
Hou, Y., Y. Hou., L. Yanyan., G. Qin and Li. Jichang. 2010. Extraction and purification of a lectin from red kidney bean and preliminary immune function studies of the lectin and four Chinese herbal polysaccharides Journal of Biomedicine and Biotechnology, Article ID 217342, 9 pages.

Lam, S. K and T. B. Ng. 2009. Novel galactonic acid-binding hexameric lectin from Hibiscus mutabilis seeds with antiproliferative and potent HIV-1 reverse transcriptase inhibitory activities. Acta Biochimica Polonica.56 (4):649-54

Lowry, O. H., N. J. Rosebrough., A. L. Farr and R. J. Randall. 1951. Protein measurement with the Folin phenol reagent. J. Biol. Chem. 193: 265-275

Medeiros, D. S., T. L. Medeiros., J. C. K. Ribeiro., N. K. V. Monteiro., L. Migliolo., A. F. Uchoa., I. M. Vasconcelos., S. Adeliana., A. S. Oliveira., M. P. de Sales., A. Elizeu and E. A. Santos. 2010. A lactose specific lectin from the sponge Cinachyrella apion: Purification,characterization, N-terminal sequences alignment and agglutinating activity on Leishmania promastigotes. Comparative Biochemistry and Physiology, Part B 155:211-216.

Munro, C. A., R. K. Whitton., H. B. Hughes., M. Rella., S. Selvaggini., N. A. R. Gow. 2003. CHS8-a fourth chitin synthase gene of Candida albicans contributes to in vitro chitin synthase activity, but is dispensable for growth Fungal Genetics and Biology 40.2: 146-158.

Naeem, A., S. Haque and R. H. Khan. 2007. Purification and Characterization of a Novelb-D-alactosides-Specific Lectin from Clitoria ternatea The Protein Journal.26. 6:403-413.

Ripoll, C., B. Favery., P. Lecomte., E. van Damme., W. Peumans., P. Abad., L. Jouanin. 2003. Evaluation of the ability of lectin from snowdrop (Galanthus nivalis) to protect plants against root-knot nematodes. Plant Sci. 164:517-523.

Roy, A., S. Banerjee., P. Majumder., and S. Das. 2002. Efficiency of Mannose-Binding Plant Lectins in Controlling a Homopteran Insect, the Red Cotton Bug. J. Agric. Food Chem. 50 (23), pp :6775-6779.

S?, RA., F. S. Gomes., T. H. Napole?o., N. D. L. Santos., C. M. L. Melo., N. B. Gusm?o., L. C. B. B. Coelho., P. M. G. Paiva and L. W. Bieber. 2009. Antibacterial and antifungal activities of Myracrodruon urundeuva heartwood. Wood Science and Technology; 43:85-95.

Santana, G. M. S., L. P. Albuquerque., D. A. Sim?es., N. B. Gusm?o., L. C. B. B. Coelho., P. M. G. Paiva. 2009. Isolation of a lectin from Opuntia ficusindica cladodes. Acta Horticulturae. 811:281-286.

Selitrennikoff, C. P. 2001. Antifungal proteins. Applied and Environmental Microbiology. 67: 2883-2894. 
Singh, T., J. H.Wu., W. J. Peumans. 2006. Carbohydrate specificity of an insecticidal lectin isolated from the leaves of Glechoma hederacea (ground ivy) towards mammalian glycoconjugates. Biochemical Journal, vol. 393, no. 1:331-341.

Sitohy, M., M. Doheim and H. Badr. 2007. Isolation and characterization of a lectin with antifungal activity from Egyptian Pisum sativum seeds. Food chemistry, 104:971979.

Tian, Q., W. Wang., C. Miao., H. Peng., B. Liu., F. Leng., L. Dai., F. Chen and J. Bao. 2007.Purification, characterization and molecular cloningof a novel mannose-binding lectin from rhizomes of Ophiopogon japonicas Sitohy M, Doheim M, Badr H. Isolation and characterization of a lectin with antifungal activity from Egyptian Pisum sativum seeds. Food Chemistry. 104:971979.

Van Asbeck, E. C., A. I. M. Hoepelman., J. Scharringa., B. L. Herpers., and J. Verhoef. 2008. Mannose binding lectin plays a crucial role in innate immunity against yeast by enhanced complement activation and enhanced uptake of polymorphonuclear cells, BMC Microbiology, vol. 8 : 229-238.

Van Damme, E. J. M., W. J. Peumans., A. Barre., and P. Rougé. 1998. Plant lectins: a composite of several distinct families of structurally and evolutionary related proteins with diverse biological roles, Critical Reviews in Plant Sciences, 17. 6:575-692.

Yan, Q., Z. Jiang., S. Yang., W. Deng and L. Han. 2005. A novel homodimericlectin from Astragalus mongholicus with antifungal activity. Arch Biochem Biophys 442:7281.

Zvereva, L. V and M. A. Vysotskaya. 2005. Filamentous fungi associated with bivalve mollusks from polluted biotopes of Ussuriiskii Bay, Sea of Japan. Russ J Mar Biol, 31:382-385.

\section{الملخص العربي \\ عزل اللكتينات النباتية و فاعليتها ضد بعض الفطريات الممرضة للتبات}

$$
\begin{aligned}
& \text { سعاد فوزي عيد محسن، مصطفى عبد اللطيف عباسي، انتصار ابر اهيم ربيع، حمدي قطب ابو طالب }
\end{aligned}
$$

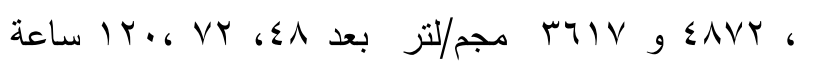

$$
\begin{aligned}
& \text { نم عزل اللكتين من بذور الفاصوليا البيضاء وبذور فول }
\end{aligned}
$$

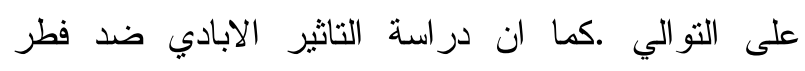

$$
\begin{aligned}
& \text { الر ايزوكتونيا سو لاني اوضحت ان لكتين الفاصوليا البيضاء }
\end{aligned}
$$

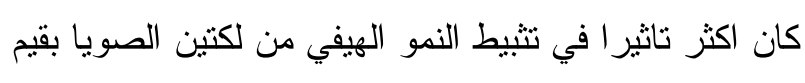

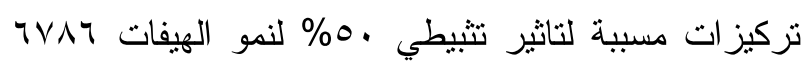

$$
\begin{aligned}
& \text { اعل } \\
& \text { الصويا و التنقية بواسطة الترسيب بكبريتات الامونيوم ونم }
\end{aligned}
$$

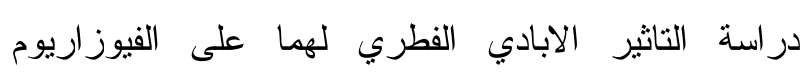

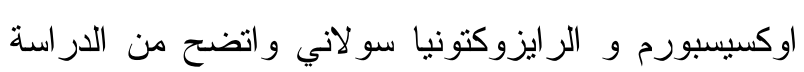

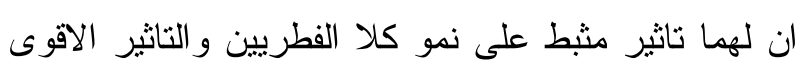

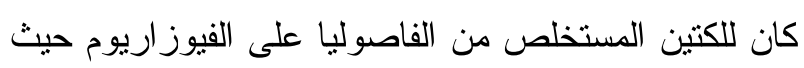

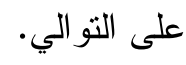

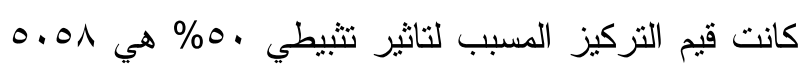

